depictions of medical practitioners, Porter suggests, grew increasingly flattering, just as newer platforms for graphic humour such as Punch (founded in 1841) and Vanity Fair (1868) - tended to eschew the coarseness and vulgarity of Georgian and Regency caricature.

Broader cultural shifts plainly fostered thesenew aesthetic conventions, but the role of changes in medicineitself isless clear. And in Porter's treatment of the nineteenth century, as throughout the book, one would have welcomed something about private representation as a counterpoint to public images and media constructs. If public representations of Victorian healersand healing shed much of their earthiness and theatricality, then what are weto make of certain more covert genres of medical self-portraiture, such as grizzly photographs depicting medical students at work in the dissecting room, or of late-Victorian advice books that unabashedly instructed doctors on how to succeed in business by putting on a good show? If the reader is left wanting more, however, it is because Porter's book is one of the best studies we have of public representations of medicine, a highly visual culture in which spectacle and ritual performance, although transformed, have hardly vanished.

John Harley Warner isin the Section of the History of M edicine, YaleU niversity School of M edicine, PO Box 208015, N ew Haven, Connecticut 06520-8025, USA.

\section{The director's tale}

\section{The Recombinant DNA}

Controversy: A Memoir. Science, Politics and the Public Interest 1974-1981

by Donald S. Fredrickson

American Society of M icrobiology Press: 2001. 408 pp. \$39.95, £32.50 (pbk)

\section{Susan Wright}

Some 25 years ago, unease within the molecular-biology community over the implications of the emerging techniques of genetic engineering triggered a major public controversyover possiblehazardsand misuse of the new field. In the United States, the National Institutes of Health $(\mathrm{NIH})$, the world's leading biomedical research institution, was designated as the government agency responsible for developing voluntary controls. The controversy quickly encompassed the nature of the controls themselves, which had been developed largely byscientists whose career (and in some cases business) interests werecloselylinked to thenew field.

Thestill-dominant view of theseevents is

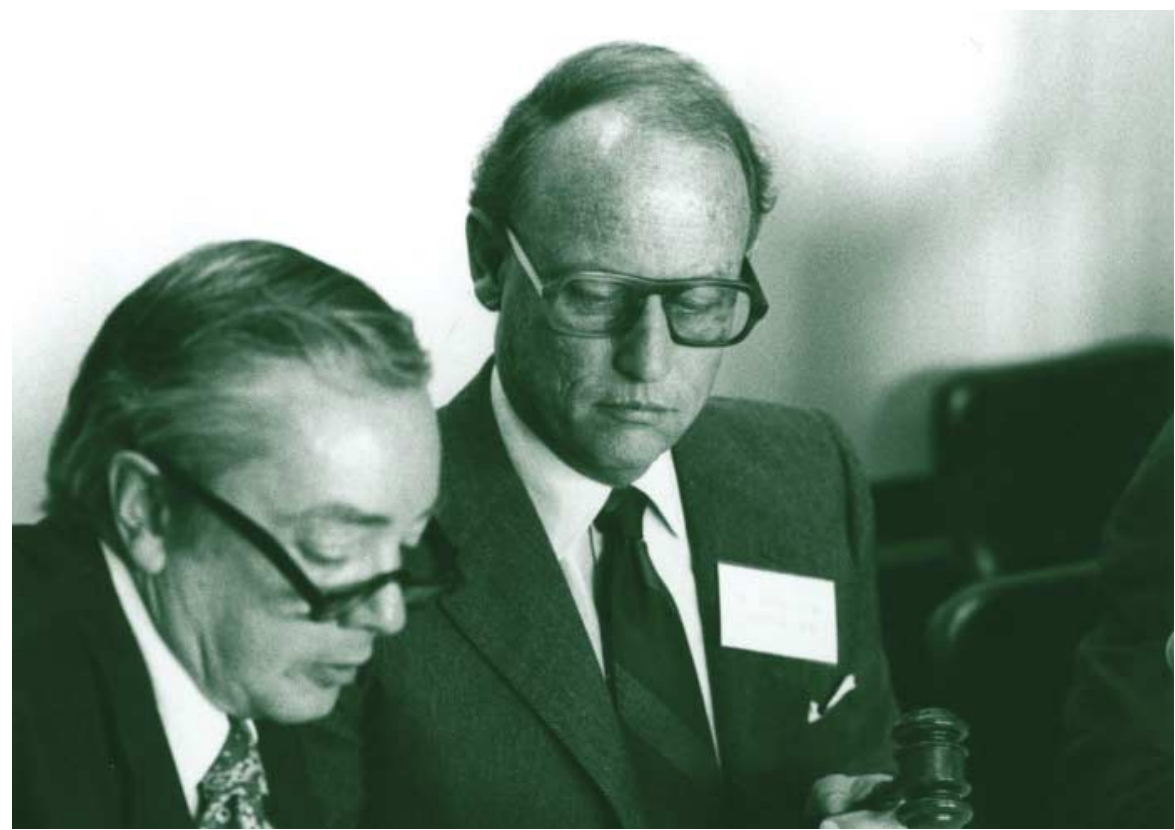

View from theinside: Fredrickson (right), seen herewith NIH committeemember Charles McCarthy.

that the American public, along with a few dissident scientists, overreacted to early concerns about the hazards of genetic engineering. Eventually, thehazards were shown to beexaggerated, allowing the $\mathrm{NIH}$ controls to bedismantled. Thisconventional wisdom casts the story as a confrontation in which rational belief in scienceultimately prevailed over irrational fear of theunknown.

Donald Fredrickson, the NIH director who presided over theriseand fall of theNIH controls, elaborates on this story with his legendary panache. Hecovers thestruggles of theNIH notonly with theattentivepublic but also behind thescenes, with theexecutiveand legislative branches of the US government. This previously invisibleface of the recombinant DNA controversy is now, apparently, revealed in Fredrickson'spapersand personal letters and diaries being deposited in the USNational Library of M edicine. Thiscollection promises to substantially augment the public record provided by the NIH and the important Recombinant DNA History Collection at the M assachusetts Institute of Technology archives.

The memoir leaves little doubt about Fredrickson's own view of the geneticengineering question as he describes the adroit manoeuvres of the NIH to protect "thegossamer quality of [its] pseudo-regulations" from conversion by the US Congress into mandatory controls that encompassed the private sector and all government agencies. Battlemetaphors permeatethisaccount of the struggle between those deemed to be 'for' or 'against' the voluntary policy espoused by the NIH. As he wrote in an unpublished article on the eve of the first major weakening of the NIH controls: "I think wehavewon asignificant victory over a dangerously excessive reaction first set in motion by scientists." The fact that policymaking in certain other countries - notably the United Kingdom - took the turn towards uniform regulation without a bitter struggleis not noted here. This is very much an American story, told by the person at the epicentre of theAmerican controversy.

But this narrative, with its strong focus on genetic engineering as a research tool, is strained. That the technique would move out of the research laboratory and into medicine, industry, agriculture and, most problematically, the military, was anticipated al most as soon as news of the first succesfful experiments began to circulate. As British molecular biologist Sydney Brenner wrote in 1974 to the British committee convened to examinegenetic engineering, there were likely to be problems of controlling "institutions which can, and probably do, practise secrecy in their activities, such as defence research laboratories and, more importantly, themajor drug companies".

This wider potential was marked by Stanford University'sapplication for a patent on the early genetic-engineering techniques - an action that sent a shock wave through the NIH as the government sponsor of this work. "'Thepatent' was widely perceived asa modestly seismic event, a nervous shift at the conjunction of the academic/not-for-profit and commercial tectonic plates sustaining the crust of the biomedical research enterprise," writes Fredrickson. From its inception, genetic engineering promised to yield socially disruptive technologies along with advances in scientific knowledge and socially useful products.

Fredrickson is aware of these larger dimensions of genetic engineering, yet they arenever allowed to intrudeon hisnarrative. During his tenure, he was in contact with 
leaders of the pharmaceutical industry who made it clear that they would adhere to "the intent and spirit" of theN IH controlsbut not necessarily to their specific requirements a position underscored by theflouting of the $\mathrm{NIH}$ controls by the rising star of the biotechnology field, Genentech, in 1978-79, when it ignored $\mathrm{NIH}$ procedures for approval of large-scalecultures of genetically modified organisms. That industry rebellion, underscoring theneed for regulation of the new industry and posing a real dilemma for the $\mathrm{NIH}$, which wanted at all costs to avoid legislation, remains invisible in this account.

Similarly, the prospect of military use of genetic engineering is mentioned but quicklydismissed on thegrounds that theproblem is addressed by the 1972 Biological Weapons Convention. That treaty has troubling loopholes, through which the genetic alteration of highly pathogenic agents of biological warfare has since slipped in the name of defence. Theseloopholeswerenot addressed when they were raised by members of Fredrickson's advisory committee in 1982; nor are these problematic developments confronted in thisaccount.

Even viewing the genetic-engineering problem through the lens of research, Fredrickson skirts a question on which his narrative depends: did the risk-assessment experiments of the 1970s clear the field of significant hazard? An important answer is contained in a transcript of thefirst scientific meeting convened at the $\mathrm{NIH}$ in 1976 to discuss risk assessment. The transcript shows a key risk-assessment experiment being designed by theparticipants not to test a worst-case scenario, but rather to reassure the public that genetic engineering was harmless. As a participant noted, without any sign of moral indignation from his colleagues, "[Thisis] molecular politics, not molecular biology". As an astute Nature reporter later observed of the treatment of the hazard question: "One must accentuate thepositive. Theevidence, however, doesnot seem substantial."

Fredrickson acknowledges that the policies he pursued as NIH director, while yielding important scientific advances and medical benefits, also opened a Pandora's box of social and ethical problems. The new evidence on the recombinant DNA controversy promised by the release of his papers, and by the release of other sources as they becomeavailable, may reveal perspectives on the controversy more troubling than the soothing onepresented in thismemoir.

Susan Wright isa historian of scienceat

Residential College, U niversity of M ichigan, East Quadrangle, Ann Arbor, M ichigan 48109-1245,

USA, and author of Molecular Politics:

Developing American and British Regulatory

Policy for Genetic Engineering, 1972-1982

(University of Chicago Press, 1994).

\section{Mitigating mutations}

The Cooperative Gene: How

Mendel's Demon Explains the

Evolution of Complex Beings/

Mendel's Demon: Gene J ustice

and the Complexity of Life

by Mark Ridley

Simon \& Schuster/Weidenfeld: 2001/2000.

320 pp. $\$ 26, £ 20$

Andrew Berry

The Cooperative Gene is a masterpiece of scientific exposition. Mark Ridley has deftly packaged a hugely complex subject - the interplay of deleterious mutation with the evolution of genetic systems - into one long argument. He has distilled an area of biology that is rife with abstruse mathematics and the arcana of molecular genetics into a series of carefully explicated thought experiments and metaphors.

Despite the reassuring presence of a glossary, Ridley even manages to avoid jargon, and in principlethebook is accessibleto the general reader. However, it is not aimed at the Stephen Jay Gould-reading (or indeed $M$ att Ridley-reading) public. It lacks the anecdotal colour that is derigueur these days if a book is to sail up the bestseller lists; there are neither pen portraits of crusty old professors peering down their microscopes nor strange tales of $Y$-linked ear hairiness in Indian men. Ridley's long argument is too dense and unrelenting to appeal to readers without a real interest in the subject; The Cooperative Gene is, in fact, a monograph masqueradingaspopular science.

Ridley'sthesisisthat thehistory of lifehas been shaped by evolution's attempts to overcometheeffects of mutation. Theoccasional mutation isbeneficial - indeed, they arethe basis of adaptive evolution - but the vast bulk of all mutation is, without doubt, deleterious: "A random mistake in the DNA is about as likely to improve the creature it codesfor as a random change in $\mathrm{H}$ amlet isto improve the play." Ridley's premise is that deleterious mutation must be kept within bounds if evolution isto occur: if theaverage rate of deleterious mutation exceeds one per genome per generation, then all the descendants of a parental generation with a mutation-free genome may be carrying deleterious mutations. Natural selection is then stymied becausenone of the competing genomes in the population is free from the taint of deleterious mutation and so it is not possible to select in favour of an intact, non-mutated genome.

Ridley sees a tension between the evolution of complexity - which necessarily involves encoding more information and therefore requires more genes - and the depredations of mutation. Assuming a constant mutation rate per nucleotide, thelarge genome of a complex being is more likely to exceed the critical threshold of one deleterious mutation per genome per generation. Ridley concludes that: "Live complexity hits its ceiling when the DNA message is so long that a mistake happens every time it is copied. When life is near this upper limit, complexity cannot evolve upwards even if there is an ecological opportunity there." The history of life has been punctuated by theevolution of "enablingmechanisms" that improve the fidelity with which hereditary information is replicated. The advent of DNA, which is less prone to degradation than RNA, asthevehiclefor that information represents one such mechanism; the evolution of error-checking and DNA-repair systems is another; and sex yet another. With each innovation, thecomplexity ceiling rose.

Also militating against the evolution of complexity are genetic el ementsthat subvert biological processes for their own 'selfish' ends, thus thwarting the cooperation between genes that is required for complexity. The simplest case of 'mendelian law-breaking' is meiotic drive, in which the probability of an allele being transmitted to the next generation is greater than the canonical mendelian expectation of $50 \%$. For Ridley, the central player in the collision between the forces that promotecomplexity and thosetrying to tear it apart ismeiosis. He emphasizes that the genetic randomization - through independent assortment and recombination - inherent in themendelian process is critical in limiting the power and spread of genetic subversion.

Ridley's summary of thelogic underlying this claim is masterful: "M endelian justice is similar to the theory of human justice given byJohn Rawlsin hisbook A Theory of Justice. Rawls argues that human beings will choose justice if they are operating behind a 'veil of ignorance'. Imagine you are going to devise or apply laws, or allocateresources, among a number of people. M aybeyou have to divide a pieamong fivepeopleincludingyourself. If you know which piece is to be received by which individual you may allocate most or all of the pie to yourself; but if you do not (you are veiled in ignorance) you may divide the pieinto equal pieces. The gene shuffling mechanisms we have been thinking about enforce M endelian justice by drawing a veil of ignoranceover thegenes."

Ridley refersto meiosis, theprimary agent of mendelian justice, as "M endel's Demon", but theimplicit parallel to science's other distinguished demon is more misleading than illuminating. In physicist James Maxwell's famous thought experiment, 'Maxwell's Demon' does the impossible: it oversees an imaginary processthatbreaksthelawsof thermodynamics. In contrast, the process overseen by M endel'sisreal: meiosisisno thought 